\title{
Comparative life cycle analysis of producing charcoal from bamboo, teak, and acacia species in Ghana
}

DOI:

10.1007/s11367-016-1220-8

\section{Document Version}

Accepted author manuscript

Link to publication record in Manchester Research Explorer

\section{Citation for published version (APA):}

Partey, S., Frith, O., Kwaku, M., \& Sarfo, D. (2016). Comparative life cycle analysis of producing charcoal from bamboo, teak, and acacia species in Ghana. International Journal of Life Cycle Assessment.

https://doi.org/10.1007/s11367-016-1220-8

\section{Published in:}

International Journal of Life Cycle Assessment

\section{Citing this paper}

Please note that where the full-text provided on Manchester Research Explorer is the Author Accepted Manuscript or Proof version this may differ from the final Published version. If citing, it is advised that you check and use the publisher's definitive version.

\section{General rights}

Copyright and moral rights for the publications made accessible in the Research Explorer are retained by the authors and/or other copyright owners and it is a condition of accessing publications that users recognise and abide by the legal requirements associated with these rights.

\section{Takedown policy}

If you believe that this document breaches copyright please refer to the University of Manchester's Takedown Procedures [http://man.ac.uk/04Y6Bo] or contact uml.scholarlycommunications@manchester.ac.uk providing relevant details, so we can investigate your claim.

\section{OPEN ACCESS}




\section{The International Journal of Life Cycle Assessment \\ Comparative life cycle analysis of producing charcoal from bamboo, teak and acacia species in Ghana \\ --Manuscript Draft--}

\begin{tabular}{|c|c|c|}
\hline Manuscript Number: & \multicolumn{2}{|l|}{ JLCA-D-15-00396R5 } \\
\hline Full Title: & \multicolumn{2}{|c|}{$\begin{array}{l}\text { Comparative life cycle analysis of producing charcoal from bamboo, teak and acacia } \\
\text { species in Ghana }\end{array}$} \\
\hline Article Type: & \multicolumn{2}{|l|}{ Original Paper } \\
\hline Corresponding Author: & \multicolumn{2}{|c|}{$\begin{array}{l}\text { Samuel Partey, PhD } \\
\text { International Network for Bamboo and Rattan } \\
\text { Kumasi, GHANA }\end{array}$} \\
\hline \multicolumn{3}{|l|}{$\begin{array}{l}\text { Corresponding Author Secondary } \\
\text { Information: }\end{array}$} \\
\hline Corresponding Author's Institution: & \multicolumn{2}{|c|}{ International Network for Bamboo and Rattan } \\
\hline \multicolumn{3}{|l|}{$\begin{array}{l}\text { Corresponding Author's Secondary } \\
\text { Institution: }\end{array}$} \\
\hline First Author: & \multicolumn{2}{|l|}{ Samuel Partey, PhD } \\
\hline \multicolumn{3}{|l|}{ First Author Secondary Information: } \\
\hline \multirow[t]{4}{*}{ Order of Authors: } & \multicolumn{2}{|l|}{ Samuel Partey, PhD } \\
\hline & \multicolumn{2}{|l|}{ Oliver Frith, MSc } \\
\hline & \multicolumn{2}{|l|}{ Michael Kwaku, MSc } \\
\hline & \multicolumn{2}{|l|}{ Daniel Akoto Sarfo, MSc } \\
\hline \multicolumn{3}{|c|}{ Order of Authors Secondary Information: } \\
\hline \multirow[t]{2}{*}{ Funding Information: } & $\begin{array}{l}\text { The Federal Ministry of Education and } \\
\text { Research }\end{array}$ & Dr Samuel Partey \\
\hline & $\begin{array}{l}\text { International Network for Bamboo and } \\
\text { Rattan }\end{array}$ & Dr Samuel Partey \\
\hline Abstract: & \multicolumn{2}{|c|}{$\begin{array}{l}\text { Purpose: The rise in wood fuel consumption and charcoal has been associated with } \\
\text { increased deforestation in Ghana. Plantation developments from teak (Tectona } \\
\text { grandis), bamboo (Bambusa balcooa) and Acacia auriculiformis are promoted to } \\
\text { produce sustainable biomass for charcoal production. While all species have } \\
\text { comparable charcoal quality, there is limited available data to elucidate the } \\
\text { environmental impacts associated with their plantation development and use as } \\
\text { biomass sources for producing charcoal. This study therefore quantified and compared } \\
\text { the cradle-to-gate environmental impacts of producing charcoal from T. grandis, A. } \\
\text { auriculiformis and B. balcooa. } \\
\text { Methods: The study was conducted in accordance with the ISO procedural framework } \\
\text { for performing LCAs in the ISO } 14040 / 14044 \text {. For this study, the functional unit chosen } \\
\text { was } 1 \text { MJ energy charcoal produced from three species: T. grandis, A. auriculiformis } \\
\text { and B. balcooa. Data on B. balcooa plantation was collected from a B. balcooa-based } \\
\text { intercropping system established by the International Network for Bamboo and Rattan } \\
\text { in the Sekyere Central District of Ghana. Input data for A. auriculiformis and T. grandis } \\
\text { were based on plantations established by the Forestry Commission of Ghana within } \\
\text { the forest agroecological zone of Ghana. All input data were from primary local data. } \\
\text { Calculations for pollutant emissions were made with Simapro version } 8 \text { applying life } \\
\text { cycle inventory (LCI) databases of Ecoinvent V3 and Idemat } 2015 \text { (a database of the } \\
\text { Delft University of Technology) to analyse the contribution of all the flow processes to } \\
\text { the emissions. The emissions were expressed as eco-costs and used as an indicator } \\
\text { for impact assessment. }\end{array}$} \\
\hline
\end{tabular}

Results and discussion: The results showed that relative to B. balcooa, the total eco- 
cost (comprising eco-cost of human health, ecosystems, resource depletion and global warming) of a cradle-to-gate production of $1 \mathrm{MJ}$ energy charcoal will be $140 \%$ higher with T. grandis and $113 \%$ higher with A. auriculiformis. The increased environmental impacts associated with T. grandis and A. auriculiformis occurred at their biomass production stage (involving nursery and plantation establishment) which constituted about $85 \%$ of the total eco-cost due to the use of relatively large quantities of pesticides, weedicides and fertilizers with high acidification, ozone depletion and global warming potentials.

Conclusions: B. balcooa plantations may be the most environmentally viable option based on the results. Where T. grandis or A. auriculiformis is a priority, improvement options will be key in reducing environmental costs at the biomass production stage for improved environmental sustainability.

Response to Reviewers:

See attachment 


\section{LCIA OF IMPACTS ON HUMAN HEALTH AND ECOSYSTEMS}

\section{Comparative life cycle analysis of producing charcoal from bamboo, teak and acacia species in} Ghana

\section{Samuel T. Partey ${ }^{1,2}$ • Oliver B. Frith • Michael Y. Kwaku' ${ }^{1}$ Daniel A. Sarfo, ${ }^{1,3}$}

Received: 27 November 2015 / Accepted: 3 November 2016

(C) Springer-Verlag Berlin Heidelberg 2016

Responsible editor: Sonia Valdivia

${ }^{1}$ International Network for Bamboo and Rattan (INBAR), International Forestry Research Center, Fumesua-Kumasi, Ashanti-Region, Ghana

${ }^{2}$ Faculty of Renewable Natural Resources, Kwame Nkrumah University of Science and Technology, PMB, Kumasi, Ghana

${ }^{3}$ Centre for Development Research (ZEF), University of Bonn, Walter-Flex-Straße 3, 53113 Bonn, Germany

\section{Samuel T. Partey}

spartey@inbar.int, stpartey@gmail.com

Tel: +233 (0) 240843963 


\section{Abstract}

Purpose: The rise in wood fuel consumption and charcoal has been associated with increased deforestation in Ghana. Plantation developments from teak (Tectona grandis or T. grandis), bamboo (Bambusa balcooa or B. balcooa) and Acacia auriculiformis (A. auriculiformis) are promoted to produce sustainable biomass for charcoal production. While all species have comparable charcoal quality, there is limited available data to elucidate the environmental impacts associated with their plantation development and use as biomass sources for producing charcoal. This study therefore quantified and compared the cradle-to-gate environmental impacts of producing charcoal from $T$. grandis, A. auriculiformis and B. balcooa.

Methods: The study was conducted in accordance with the ISO procedural framework for performing LCAs in the ISO 14040/14044. For this study, the functional unit chosen was 1 MJ energy charcoal produced from three species: T. grandis, A. auriculiformis and B. balcooa. Data on B. balcooa plantation was collected from a $B$. balcooa-based intercropping system established by the International Network for Bamboo and Rattan in the Sekyere Central District of Ghana. Input data for A. auriculiformis and $T$. grandis were based on plantations established by the Forestry Commission of Ghana within the forest agroecological zone of Ghana. All input data were from primary local data. Pollutants' emissions were calculated in order to analyze the contribution of all the flow processes to the emissions. This was done by using Simapro version 8 , life cycle inventory (LCI) databases of Ecoinvent V3 and Idemat 2015 (a database of the Delft University of Technology). The emissions were expressed as eco-costs and used as indicators for impact assessment.

Results and discussion: The results showed that relative to B. balcooa, the total eco-cost (comprising eco-cost of human health, ecosystems, resource depletion and global warming) of a cradle-to-gate production of $1 \mathrm{MJ}$ energy charcoal will be $140 \%$ higher with $T$. grandis and $113 \%$ higher with $A$. auriculiformis. The increased environmental impacts associated with $T$. grandis and A. auriculiformis occurred at their biomass production stage (involving nursery and plantation establishment) which constituted about $85 \%$ of the total eco-cost due to the use of relatively large quantities of pesticides, weedicides and fertilizers with high acidification, ozone depletion and global warming potentials.

Conclusions: The study results suggest that B. balcooa plantations are the most environmentally viable option. In cases where T. grandis or A. auriculiformis plantation sare widespread, improvement options at the biomass production stage are required in order to reduce the environmental costs.

Keywords Charcoal $\bullet$ Eco-cost $\bullet$ Forest plantation $\bullet$ Life cycle analysis $\bullet$ Wood fuels 


\section{Introduction}

According to FAO and JRC (2012), Africa loses about 1.6 million hectares of forest annually. Whilst current rate is still alarming considering the huge dependence of about $90 \%$ of the African populace on forest resources and non-timber forest products. The FAO and JCR (2012) estimated the annual deforestation rate in Ghana as $2.1 \%$ per year, which corresponds with an average annual forest loss of 115,000 ha. This estimate is about $100 \%$ increment of the 65,140 ha per annum rate reported by ITTO (2005). The forest cover of Ghana that contained over 300 timber species has reduced from 8.2 million hectares in 1984 to the current cover area of 1.3 million hectares (Agyemang et al. 2012). Most interventions and policies, such as introducing annual allowable cuts of 1 million $\mathrm{m}^{3}$ of round logs and bans on illegal chainsaw operation, have not reduced the pressure on forests. This is attributed to the fact that some of the poorest, rural people depend on the forest for their livelihoods. Available literature points to the fact that fuelwood consumption is one major cause of deforestation in Ghana. It is estimated that 14 million $\mathrm{m}^{3}$ of wood are annually consumed for energy production in Ghana. Similar to many parts of Africa, wood fuels currently provide $71 \%$ of the total annual energy demand in Ghana (Energy Commission of Ghana 2015) and the annual per capita consumption of charcoal for cooking and heating in Ghana is also estimated to be $180 \mathrm{~kg}$ (Agyemang et al. 2012). With rising household energy demands, the rates of deforestation and the concomitant negative effects on ecosystem services are set to increase unless alternate sustainable pathways are developed.

In Ghana, sustainable forest management has been made a priority, with government and scientists now advocating for the use of bamboo to reduce pressure on major commercial timber species sometimes sourced for household energy needs. Bamboo's characteristics of fast growth and high renewability make it an efficient and renewable substitute resource for charcoal production. Although bamboo is underutilized in Ghana, there are currently more than 300,000 ha of bamboo (Obiri and Oteng-Amoako 2007) covering about $5 \%$ of total Ghana's forest land. With about $30 \%$ yield rate, Ghana has a strong potential to produce 0.9 million tons of bamboo charcoal on a sustainable basis which could potentially replace $64 \%$ of the country's wood consumption for charcoal production (Obiri and Oteng-Amoako 2007). Besides bamboo, the forestry commission and some nongovernmental organizations in Ghana continue to promote plantations of teak ( $T$. grandis) and A. auriculiformis for wood fuel and charcoal production. T. grandis plantations form over 50 per cent of the estimated 100,000 ha of productive plantations belonging to the Forests Services Division (FSD) of the Forestry Commission of Ghana. There are also about 70,000 ha of private plantations distributed in the ten regions of the country of which T. grandis forms the major component (OtengAmoako and Sarfo 2005). While the charcoal quality (in relation to energy production, smokiness, hardness and ash contents) of the tree species and bamboo may be comparable, there is limited available data to inform the environmental impacts associated with their plantation development and use as biomass sources for producing charcoal. It was therefore the objective of this study to quantify and compare the environmental impacts of producing charcoal from T. grandis, A. auriculiformis and 
B. balcooa. This information will highlight a number of improvement options or impact reduction strategies that can enhance the environmental sustainability of charcoal production in Ghana.

\section{Materials and methods}

2.1 Species used in the study

Species used in the study included Acacia auriculiformis, Tectona grandis and Bambusa balcooa. Summaries of these species are provided in Table 1.

\subsection{The LCA methodology}

\subsubsection{System boundary and functional unit}

The study was conducted in accordance with the ISO procedural framework for performing LCAs in the ISO 14040/14044 (2006). For this study, the functional unit (FU) chosen was $1 \mathrm{MJ}$ energy charcoal produced from the three species. The system studied was divided into the following stages: (1) Biomass production including plantation development from nursery, (2) harvesting and processing of biomass; (3) transportation involving transport of biomass to charcoal production site; and (4) carbonization and packaging of charcoal. The production system and its boundary limits are shown in Fig. 1.

\subsubsection{Data collection and analysis}

The LCA neglected the life cycle tracing of fixed assets such as the kiln for charcoal production, greenhouse structures for nursery, offices, equipment, cold-rooms or refrigerators for storing seeds/propagules as well as marketing and utilization of charcoal. Meanwhile, the study included the cradle-to-gate production of all operational inputs used by plantation developers/farmers and charcoal producers at every stage of the charcoal production chain. The operational inputs included planting materials, fertilizers, pesticides, weedicides, irrigation water, wood (for charcoal production), gasoline (petrol) and diesel. In all cases, charcoal was produced in traditional brick kilns and the energy values were determined using a Krocher oxygen bomb calorimeter. Background information on the production of fertilizers, used weedicides and pesticides and transportation were obtained by referring to the Idemat 2015 database of the Delft University of Technology, which is partly based on Ecoinvent Unit data. Emissions due to fertilizer, weedicide and pesticide use were quantified by using estimation methods described by Hauschild et al. (2000) and Heathwaite et al. (2000). Inventory data for transportation was calculated based on average distance of $250 \mathrm{~km}$ traveled by diesel engine trucks in Ghana (Ntiamoah and Afrane 2008). The truck used for the analysis was assumed to be 22 tons total capacity/14.5 tons payload/long distance truck. Input data on B. balcooa was collected from a $B$. balcooa-based intercropping system established by the International Network for Bamboo and Rattan in the Sekyere Central District of Ghana. Input data for A. auriculiformis and T. grandis were based on plantations established by the Forestry Commission of Ghana within the forest agroecological zone of Ghana. All plantations compared were from the same agroecological zone. 
All input data were from primary local data. A summary of the inventory data collected are presented in Table 2. The pollutants' emissions were calculated by applying the software Simapro version 8 , the University of Technology). The analysis of the contribution of all the flow processes to the emissions was based on the CML 2001 method. The emissions were expressed as eco-costs using the multipliers in Table 3 reported at the Ecocost value website (2016). The eco-costs method is used to assess the impacts along the life cycle (life cycle impact assessment, LCIA). The eco-costs express the amount of environmental burden on the basis of prevention of that burden. Eco-costs are related to the costs which should be incurred in order to reduce the environmental pollution and materials depletion in our economy to a level which is in line with the carrying capacity of our earth (Vogtländer et al. 2010). Eco-costs are "marginal prevention costs". As such, the eco-costs are virtual costs, since they are not yet integrated in the real life costs of current production chains (Life Cycle Costs). The ecocosts are calculated for the situation of the European Union, but are applicable worldwide under the assumption of a level playing field for business, and under the precautionary principle. The character of prevention measures is that the costs of prevention will counterbalance the damage costs of environmental pollution (e.g. damage costs related to human health problems). So the total effect of prevention measures on our society is that it results in a better environment at virtually no extra costs, since costs and savings will level out (Ecocost value website 2016).

The total eco-cost results by adding the eco-costs at the four endpoint impact categories (eco-costs of human health, eco-costs of ecosystems, eco-costs of resource depletion and eco-costs of global warming) which individually were calculated as follows:

- eco-costs of human health $=$ the sum of carcinogens and fine dust

- eco-costs of ecosystems $=$ the sum of acidification, eutrophication and ecotoxicity

- eco-costs of resource depletion $=$ the sum of abiotic depletion, land-use, water, and land-fill

- eco-costs of global warming $=$ the sum of $\mathrm{CO}_{2}$ and other greenhouse gases

\section{Results and discussion}

\subsection{Heat value of charcoal produced}

The calorific values of charcoal produced from the three species were generally comparable: $B$. balcooa $\left(27.2 \mathrm{MJ} \mathrm{kg}^{-1}\right)$, A. auriculiformis $\left(28.9 \mathrm{MJ} \mathrm{kg}^{-1}\right)$ and $T$. grandis $\left(29.2 \mathrm{MJ} \mathrm{kg}^{-1}\right)$. The range of values obtained is consistent with previous estimations (Rousset et al. 2011; Fuwape 1993; Orwa et al. 2009). From the results obtained, there are clear indications that more B. balcooa wood will be required to produce the same amount of heat as A. auriculiformis and T. grandis. However, this is only in the short term as B. balcooa has high coppicing ability. With regards to the functional unit, the production of $1 \mathrm{MJ}$ energy will require the combustion of $3.68 \mathrm{E}-02 \mathrm{~kg}, 3.42 \mathrm{E}-02 \mathrm{~kg}$ and $3.46 \mathrm{E}-02 \mathrm{~kg}$ of B. balcooa, A. auriculiformis and T. grandis charcoals respectively. Considering an average of about $32 \%$ charcoal yield per kilogram of each of the wood biomass used, charcoal producers will harvest (on dry weight basis), 7.84E-02 kg, 7.28E-02 kg and 7.37E-02 kg of B. balcooa, A. 
auriculiformis and T. grandis respectively for $1 \mathrm{MJ}$ of energy. This implies that for the same household or industrial energy requirements, more B. balcooa species than $T$. grandis and $A$. auriculiformis will be harvested per hectare of land at least within the first charcoal production year.

\subsection{Comparative assessment of impacts related to the species used}

\subsubsection{Total eco-cost}

Table 4 shows the total eco-cost associated with the three species and flow processes with respect to the functional unit. The total eco-cost (comprising effects of emissions on human health, ecosystems, resource depletion and global warming) was comparable between A. auriculiformis and T. grandis but comparatively lower in B. balcooa. The analysis revealed that relative to $B$. balcooa, the environmental cost of a cradle-to-gate production of $1 \mathrm{MJ}$ energy content of charcoal will be $140 \%$ higher with T. grandis and $113 \%$ higher with A. auriculiformis (Fig. 2). The increased total environmental cost with $T$. grandis and A. auriculiformis may be associated with the high eco-cost on the four endpoint impact categories (human health, ecosystems, resource depletion and global warming) as influenced by chemical inputs and management practices. Compared with the other flow processes, the results showed inputs for nursery and field plantation establishment and management accounted for $83 \%, 88 \%$ and $86 \%$ of the total eco-cost for T. grandis, B. balcooa and A. auriculiformis respectively (Table 4). This shows substantial reductions in environmental cost could be achieved by seeking alternative approaches to the use of chemicals for improving soil fertility; and controlling weeds, pests and diseases which dominate cultural practices at the nursery and field establishment stages. Although data used in the life cycle inventory were mainly from primary sources, values obtained as total eco-cost for assessing the environmental impacts of the three species may be specific to the plantations used as case studies in the present study. Meanwhile, the results are relevant for making country-wide recommendations since the plantations used in this study follow the general cultural practices employed in high-input T. grandis, A. auriculiformis and B. balcooa plantations in Ghana.

\subsubsection{Eco-cost of human health}

Compared with B. balcooa, the eco-cost of human health (comprising the sum of carcinogens and fine dust) was higher with $T$. grandis and A. auriculiformis and contributed to about $11 \%$ of their total eco-cost (Fig. 3). The results imply that compared with B. balcooa, the production of $1 \mathrm{MJ}$ energy charcoal from A. auriculiformis and T. grandis may pose greater human health risks. This may be attributed to the greater release of carcinogens and dust particles associated with chemical inputs during tree nursery establishment and field plantation management (van der Lugt et al. 2008). While chemicals were used for all species, site and species specific requirements may have accounted for the differences in human health risks recorded. Although these results are typical of state-funded commercial or high input plantations (such as those used in this study), managed plantations by resource-poor smallholder farmers are expected to pose low human health risks. 


\subsubsection{Eco-cost of ecosystems}

The eco-cost of ecosystems ranged from $€ 3.79 \mathrm{E}-08$ in B. balcooa to $€ 9.46 \mathrm{E}-07$ in $T$. grandis. The highest cost on ecosystems with $T$. grandis may be attributed to increased acidification, eutrophication and ecotoxicities associated with the application of fertilizers. Fertilizer requirements of T. grandis were comparatively the highest. Young T. grandis plantations typically receive $163 \mathrm{~kg} \mathrm{ha}^{-1}$ urea, 375 $\mathrm{kg} \mathrm{ha}^{-1}$ rock phosphate, $145 \mathrm{~kg} \mathrm{ha}^{-1}$ muriate of potash, and $373 \mathrm{~kg} \mathrm{ha}^{-1} \mathrm{Mg}$ sulphate from two split applications in the first year and four split applications during the second and third years (FernándezMoya et al. 2014). Both B. balcooa and A. auriculiformis require about half of that used in T. grandis production (Growmore Biotech Ltd 2015). Particularly with A. auriculiformis, its N-fixing ability requires limited application of $\mathrm{N}$ fertilizers during early establishment stages although substantial amount of $\mathrm{P}$ is generally required for increased $\mathrm{N}$ fixation and growth of the species (Orwa et al. 2009). Considering the higher application of fertilizers with $T$. grandis, increased acidification may have resulted from the emissions of $\mathrm{NH}_{3}$ due to volatilization during and after application of fertilizers (urea) (Brentrup et al. 2000). Further, eutrophication of aquatic ecosystems is unavoidable with the leakage of nutrients from fertilizers (especially phosphates) used during early field transplant of seedlings. Most of the impact on ecosystem may have therefore resulted from eutrophication by organic and inorganic fertilizer application and the emission of nitrous oxide and ammonia from the application of $\mathrm{N}$ fertilizers.

\subsubsection{Eco-cost of resource depletion}

For all species, another important environmental issue of concern is loss of biodiversity and ecosystem services. Large quantities of healthy and genetically diverse native flora and fauna are an indication of a balanced ecosystem (Narayanaswamy et al. 2002) which is generally lost in plantation establishments (especially with introduced species). Resource depletion accounted for $23 \%, 44 \%$ and $21 \%$ of the total eco-cost associated with $1 \mathrm{MJ}$ energy charcoal produced from T. grandis, B. balcooa and A. auriculiformis respectively. A major recommendation to reducing environmental costs associated with resource depletion is adherence to mixed plantations or agroforestry practices that conserve biodiversity and preserve ecosystem services. Particularly with T. grandis, Orwa et al. (2009) recommended that due to the deciduous physiology, pure $T$. plantations must be avoided. Instead, plantation developers may raise up to $80 \%$ of mixed indigenous species and $20 \%$ T. grandis. Such integrated systems have the propensity to reduce environmental degradation and preserve ecosystem services. Whilst $T$. grandis intercropping systems are rare in Ghana, the integration of crops into B. balcooa is particularly being promoted for food security and renewable energy production. Further, considering that A. auriculiformis is a soil improver, plantations that involve the integration of crops may improve soil fertility and crop production. Increased agrobiodiversity with the species will therefore improve significant ecosystem services and reduce environmental burden. 


\subsubsection{Eco-cost of global warming}

The eco-cost of global warming was found to be relatively greater in $T$. grandis ( $€ 1.99 \mathrm{E}-06)$ and $A$. like carbon dioxide $\left(\mathrm{CO}_{2}\right)$ (Brentrup et al. 2004). Among the end point impact categories, global warming was the most significant and was hugely influenced by nursery and field management operations (Table 4). In B. balcooa, eco-cost of global warming formed the most significant proportion $(51 \%)$ of its total eco-cost (Fig. 3). This may also necessitate reducing the use of chemicals with $B$. balcooa production and switching to more environmentally viable alternatives. This notwithstanding, increased carbon sequestration in the long term could potentially offset the carbon footprints associated with charcoal production from B. balcooa. Carbon sequestration rate in a 4-year old B. balcooa ideal for charcoal production is estimated to be about $400 \mathrm{~kg} \mathrm{C}^{-1} \mathrm{yr}^{-1}$ (Growmore Biotech Ltd 2015). These values are about four times higher than that estimated for T. grandis (Kraenzel et al. 2003) and A. auriculiformis (Nair et al. 2009). This implies that while all species could offset their carbon footprints through time, the potential varies with respect to their physiology and management. In the first year of charcoal production, we anticipate more B. balcooa species than T. grandis and A. auriculiformis may be harvested per hectare of land to produce the same household or industrial energy requirements. However, with high coppicing ability of B. balcooa, one-time plantation establishment (involving the application of fertilizers and pesticides) may be enough to sustain biomass production for several years. This will curtail emissions at the biomass production stage and cut down on its total eco-cost. Scholarly information attests that B. balcooa once established can be harvested every year or two for about 100 years (Growmore Biotech Ltd 2015). Significant carbon footprints (with respect to a cradle-to-gate charcoal production) will therefore be reflected in the use of chain saws during harvest, pyrolysis of biomass during charcoal production and transport which all recorded less than $10 \%$ of the total eco-cost (Table 4). With high renewability of $B$. balcooa and its carbon sequestration potential, the carbon footprint of producing charcoal from $B$. balcooa will be insignificant in the long term. The same is expected for $T$. grandis and $A$. auriculiformis except that (in comparison with B. balcooa) they have relatively slow growth and long rotation cycles (5 years) for charcoal production (Orwa et al. 2009). Additionally, due to the relative difficulty of coppicing these two trees, both highly dependent on management, farmers may have to raise new seedlings (with traces of carbon footprints) after every rotation cycle to meet biomass requirements for charcoal production (Orwa et al. 2009).

\section{Conclusions}

The results suggest that charcoal production from T. grandis, B. balcooa and A. auriculiformis pose differentiated environmental impacts. T. grandis recorded the greatest impacts on global warming (with eco-costs amounting to $€ 1.99 \mathrm{E}-06$ ), on human health (with $€ 4.92 \mathrm{E}-07$ as eco-costs) and ecosystems (resulting eco-costs: $€ 4.96 \mathrm{E}-07$ ) while B. balcooa had the greatest impact on natural resources depletion $(€ 1.41 \mathrm{E}-06)$ referring to the three species analysed. While the results showed that 
more B. balcooa species may be required than T. grandis and A. auriculiformis to produce $1 \mathrm{MJ}$ energy charcoal, the overall assessment showed that compared to B. balcooa, the total eco-cost (comprising eco-cost of human health, ecosystems, resource depletion and global warming) of a cradle-to-gate production of $1 \mathrm{MJ}$ energy charcoal will be $140 \%$ higher with T. grandis and $113 \%$ higher with A. auriculiformis. The increased environmental impacts associated with $T$. grandis and A. auriculiformis occurred at their biomass production stage (involving nursery and plantation establishment) which constituted about $85 \%$ of the total eco-cost due to the use of relatively large quantities of pesticides, weedicides and fertilizers with high acidification, ozone depletion and global warming potentials. In cases where $T$. grandis or A. auriculiformis plantations are widespread, improvement options, such as the use of organic alternatives (like neem extracts) for pest control and compost for plant nutrient supply, are required to reduce environmental impacts and help to improve the sustainability of these practices.

However, our results indicate that B. balcooa plantations are likely to be the most environmentally sustainable option for meeting Ghana's growing charcoal demand. The results of this study should be relevant to policy makers and stakeholders of Ghana's forestry sector for potential policy changes and district level recommendations that ensure sustainable forest management and natural resource governance in Ghana.

Acknowledgements This paper is supported by the International Network for Bamboo and Rattan and the BiomassWeb project with funding support from the German Federal Ministry of Education and Research Germany. We also thank Dr. Vogtländer, J for sharing the LCA database.

\section{References}

Agyemang KO, Amponsah O, Braimah I, Lurumuah S (2012) Commercial charcoal production and sustainable community development of the upper west region, Ghana. J Sustain Dev 5:149164

Brentrup F, Küsters J, Kuhlmann H, Lammel J (2004) Environmental impact assessment of agricultural production systems using the life cycle assessment methodology: I. Theoretical concept of a LCA method tailored to crop production. Eur J Agron 20:247-264

Brentrup F, Küsters J, Lammel J, Kuhlmann H (2000) Methods to estimate on-field nitrogen emissions from crop production as an input to LCA studies in the agricultural sector. Int $\mathbf{J}$ Life Cycle Assess 5:349-357

Eco-cost value website (2016) The Model of the Eco-costs / Value Ratio (EVR). http://www.ecocostsvalue.com/EVR/model/theory/subject/2-eco-costs.html

Energy Commission of Ghana (2015) National Energy Statistics 2005 - 2014. Available at http://energycom.gov.gh/files/Energy\%20Statistics_2015.pdf. Accessed on $15^{\text {th }}$ November 2015 
FAO (2010) Global forest resources assessment 2010. Food and Agriculture Organization of the United Nations, Rome

FAO, JRC (2012) Global forest land-use change 1990-2005. FAO forestry paper, 169.Fuwape JA (1993) Charcoal and fuel value of agroforestry tree crops. Agroforest Syst 22:175-179

Fernández-Moya J, Alvarado A, San Miguel-Ayanz A, Marchamalo-Sacristán M (2014) Forest nutrition and fertilization in teak (Tectona grandis Lf) plantations in Central America. New Zeal J For Sci 44 (Suppl 1):S6

Growmore Biotech Ltd (2015) Development of "Beema. Available at http://www.growmorebiotech.com/beema1.htm. Accessed on $18^{\text {th }}$ October, 2015

Hauschild M (2000) Estimating pesticide emissions for LCA of agricultural products. In: Weidema BP, Meeusen MJG, (editors). Agricultural data for life cycle assessment, vol. II. The Hague: Agricultural Economics Research Institute

Heathwaite L (2000) Flows of phosphorous in the environment: identifying pathways of loss from agricultural land. In: Weidema BP, Meeusen MJG, editors. Agricultural data for life cycle assessment, vol. 2. The Hague: Agricultural Economics Research Institute

ISO 14044 (2006) Environmental management - Life cycle assessment - Requirements and guidelines (ISO 14044:2006), ISO, Geneva

ITTO (2005) Ghana country profile, Status of tropical forest management (2005). [http://www.itto.or.jp/live/Live_Server/1233/Ghana.e.pdf]. Accessed on $1^{\text {st }}$ April, 2015

Karmacharya SB, Singh KP (1992) Biomass and net production of teak plantations in a dry tropical region in India. Forest Ecol Manag 55:233-247

Kraenzel M, Castillo A, Moore T, Potvin C (2003) Carbon storage of harvest-age teak (Tectona grandis) plantations, Panama. Forest Ecol Manag 173:213-225

Nair PKR, Nair VD, Kumar BM, Haile SG (2009) Soil carbon sequestration in tropical agroforestry systems: a feasibility appraisal. Sustainability impact assessment and land-use policies for sensitive regions. Environ Sci Technol 12:1099-1111

Narayanaswamy V, Altham J, Van Berkel R, McGregor M (2002) A primer on environmental life cycle assessment (LCA) for Australian grains. Curtin University of Technology, http://cleanerproduction.curtin.edu.au

Ntiamoah A, Afrane G (2008) Environmental impacts of cocoa production and processing in Ghana: life cycle assessment approach. J Cleaner Prod 16:1735-1740

Obiri BD, Oteng-Amoako AA (2007). Towards a sustainable development of the bamboo industry in Ghana. Ghana J Forest 21:14-27

Orwa C, Mutua A, Kindt R, Jamnadass R, Anthony S (2009) Agroforestree Database:a tree reference $\begin{array}{llll}\text { and } & \text { selection } & \text { guide } & \text { version }\end{array}$ (http://www.worldagroforestry.org/sites/treedbs/treedatabases.asp)Oteng-Amoako A, Sarfo D (2005) Development of teak plantations in Ghana: propagation, processing, utilization and 
marketing. In ITTO/Kerala Forest Research Institute International Conference on Quality Timber Products of Teak from Sustainable Forest Management, Peechi, India

Rousset P, Aguiar C, Labbé N, Commandré JM (2011) Enhancing the combustible properties of bamboo by torrefaction. Bioresour Technol 102:8225-8231

Shanmughavel P, Francis K (1996) Biomass and nutrient cycling in bamboo (Bambusa bambos) plantations of tropical areas. Biol Fert Soils 23:431-434

van der Lugt P, Vogtländer J, Brezet H (2008) Bamboo, a Sustainable Solution for Western Europe: Design Cases LCAs and Land-use. Centre for Indian Bamboo Resource and Technology Vogtländer J, Van der Lugt P, Brezet H (2010) The sustainability of bamboo products for local and Western European applications. LCAs and land-use. J Cleaner Prod 18:1260-1269 


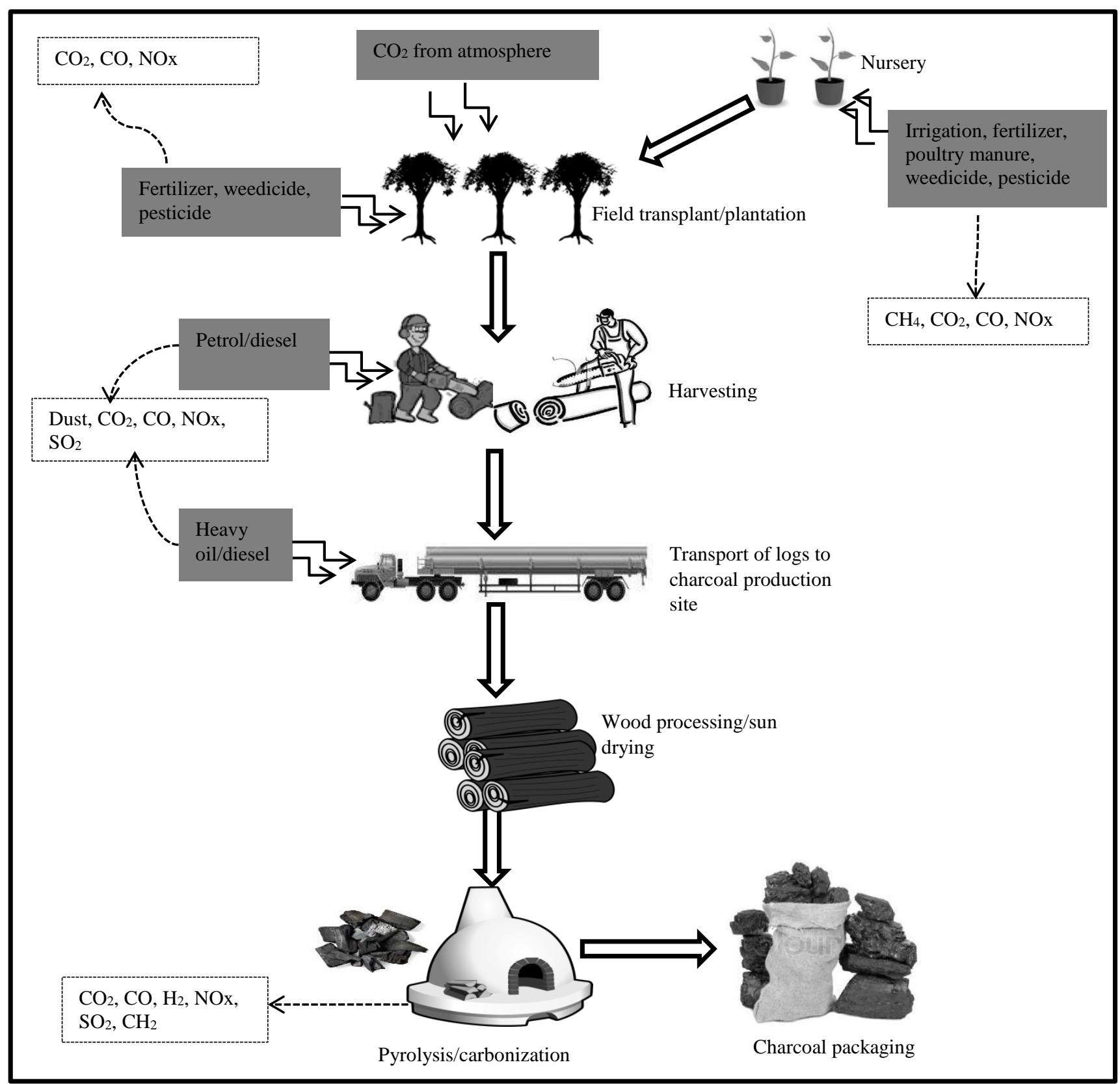

Fig. 1 System boundary: cradle-to-gate charcoal production from biomass production to packaging. Shaded boxes are inputs, block arrows the flow processes, boxes with dash lines are emissions, elbow arrow shows which process the inputs are added, dash arrows shows what is emitted from the processes 


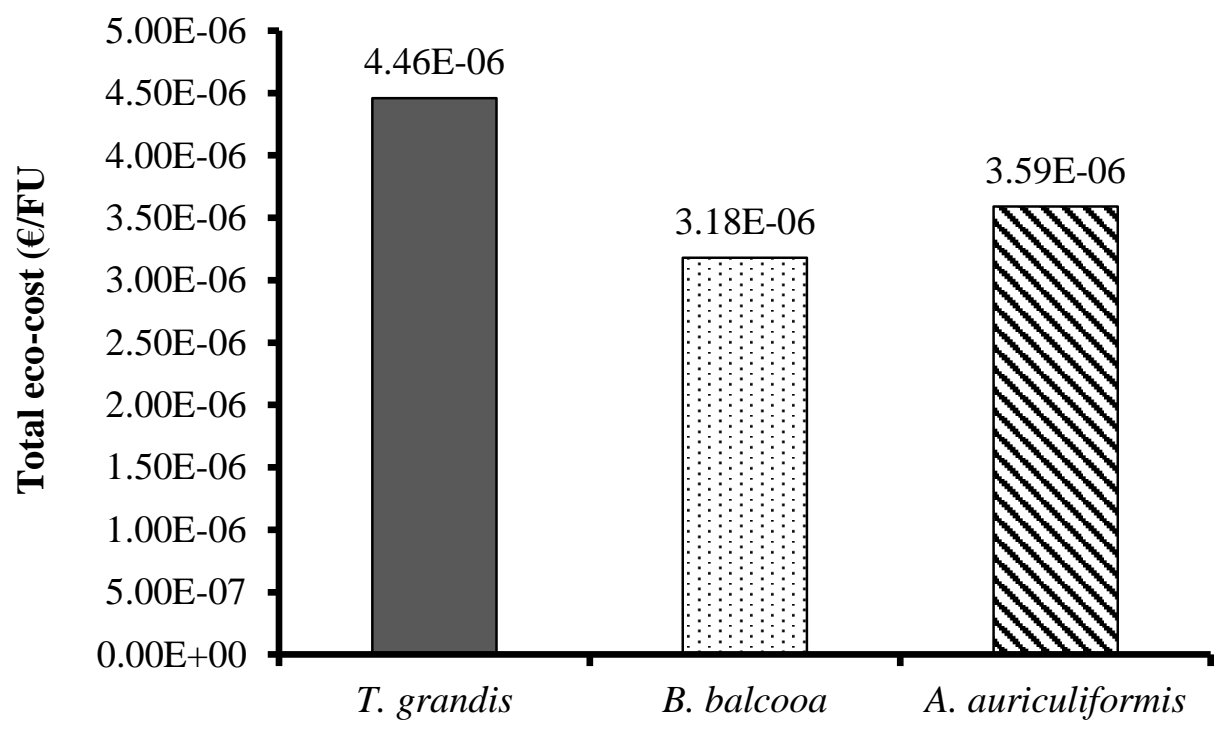

Fig. 2 Total eco-cost of a cradle-to-gate production of $1 \mathrm{MJ}$ energy of charcoal produced from $T$. grandis, B. balcooa and A. auriculiformis in Ghana 


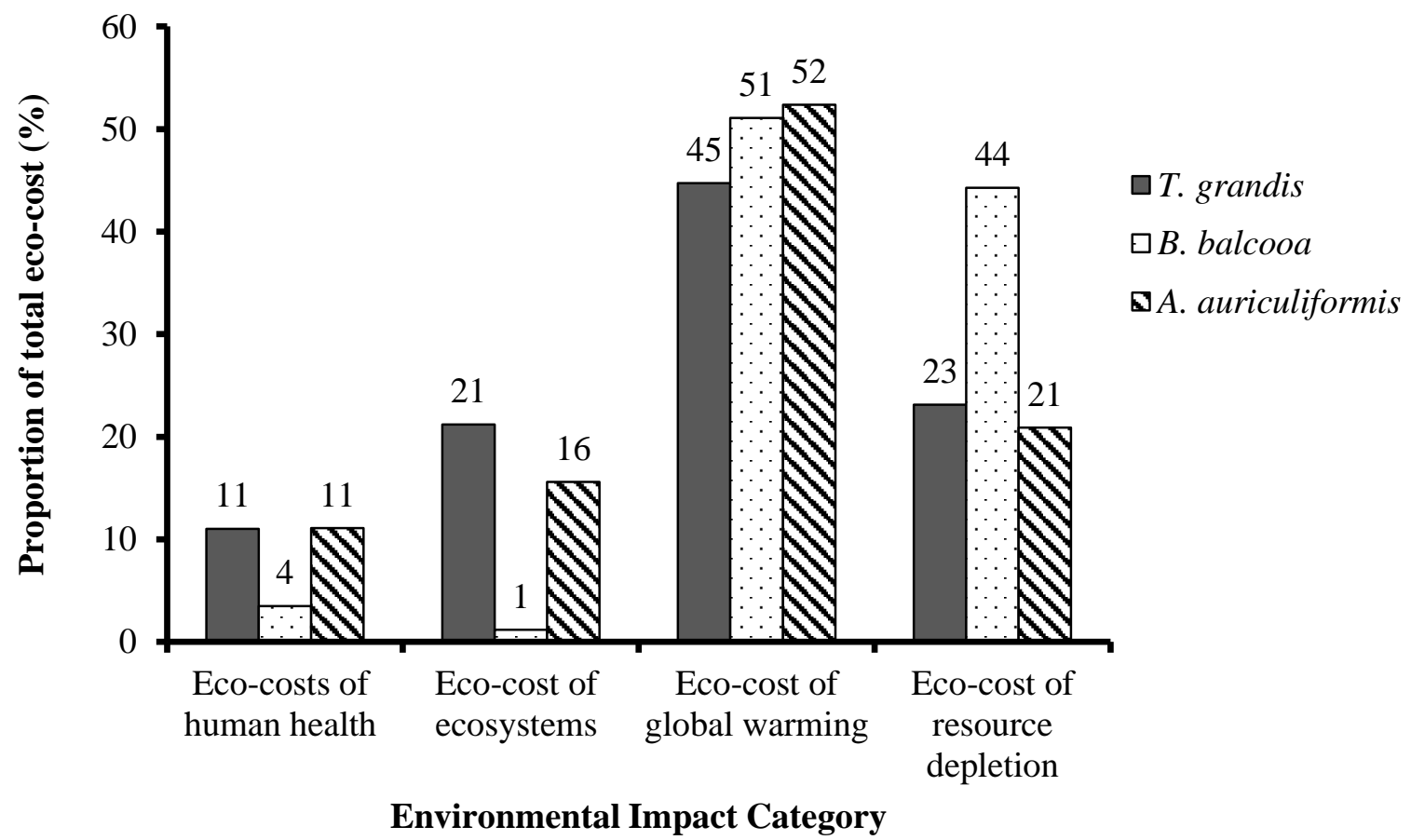

Fig. 3 Impact categories and their proportion of the total environmental burden for producing 1 MJ energy of charcoal produced from T. grandis, A. auriculiformis and B. balcooa in Ghana 
Table 1 Summarized description of species used in the study

\begin{tabular}{|c|c|c|c|}
\hline Characteristics & Acacia auriculiformis & Bambusa balcooa & Tectona grandis \\
\hline Family & Fabaceae - Mimosoideae ${ }^{1}$ & Poaceae & Lamiaceae \\
\hline Common name (s) & $\begin{array}{l}\text { Japanese acacia, } \\
\text { Australian wattle, coast } \\
\text { wattle, Darwin black } \\
\text { wattle, earleaf acacia }^{1}\end{array}$ & Beema $^{3}$ & Teak $^{1}$ \\
\hline Climate range & Tropical $^{1}$ & Tropical $^{3}$ & Tropical $^{1}$ \\
\hline $\begin{array}{l}\text { Average height }(\mathrm{m}) \text { at } \\
\text { physiological maturity }\end{array}$ & $30^{1}$ & $35^{3}$ & $30^{1}$ \\
\hline $\begin{array}{l}\text { Wood calorific value of } \\
\text { species }\left(\mathrm{Kcal} \mathrm{kg}^{-1}\right)\end{array}$ & $4500-4900^{1}$ & $4000-4650^{3}$ & $4400-4900^{1}$ \\
\hline $\begin{array}{l}\text { Average total carbon } \\
\text { stock }\left(\mathrm{t} \mathrm{ha}^{-1}\right) \text { at ten year } \\
\text { old }\end{array}$ & $180.9^{1}$ & $165.1^{4}$ & $181.3^{1,5}$ \\
\hline $\begin{array}{l}\text { Rotation period (years) } \\
\text { for fuelwood }\end{array}$ & $4-5^{1}$ & $5^{3}$ & $5^{1}$ \\
\hline $\begin{array}{l}\text { Average yield production } \\
\text { ( } \% \text { charcoal per dry } \\
\text { weight of wood) }\end{array}$ & $32^{1}$ & $30^{3}$ & $33^{1}$ \\
\hline $\begin{array}{l}\text { Calorific value of } 1 \mathrm{~kg} \text { of } \\
\text { charcoal produced with } \\
\text { each species }\left(\mathrm{Kcal} \mathrm{kg}^{-1}\right)\end{array}$ & $6907^{2}$ & $6501^{2}$ & $6979^{2}$ \\
\hline $\begin{array}{l}\text { Orwa et al. (2009) } \\
{ }^{2} \text { Measured by authors } \\
\text { 36rowmore Biotech Ltd (20 } \\
\text { Shanmughavel and Francis } \\
5 \text { Karmacharya and Singh (19 }\end{array}$ & $\begin{array}{l}\text { 5) } \\
(1996) \\
92)\end{array}$ & & \\
\hline
\end{tabular}


Table 2 Input and output data for 1 MJ energy content of charcoal produced from T. grandis, A. auriculiformis and B. balcooa plantations in Ghana

\begin{tabular}{|c|c|c|c|c|}
\hline \multirow[t]{2}{*}{ Inputs/outputs } & \multicolumn{3}{|l|}{ Amount } & \multirow[t]{2}{*}{ Unit } \\
\hline & B. balcooa & T. grandis & A. auriculiformis & \\
\hline \multicolumn{5}{|l|}{ Energy inputs } \\
\hline Petrol & $6.92 \mathrm{E}-03$ & $7.36 \mathrm{E}-03$ & $6.84 \mathrm{E}-03$ & $\mathrm{~kg}$ \\
\hline Diesel & $1.49 \mathrm{E}-02$ & $1.58 \mathrm{E}-02$ & $1.47 \mathrm{E}-02$ & $\mathrm{~kg}$ \\
\hline \multicolumn{5}{|l|}{ Material inputs } \\
\hline Water & 1.38E-04 & $1.47 \mathrm{E}-04$ & $1.37 \mathrm{E}-04$ & $\mathrm{~kg}$ \\
\hline Fertilizer & $1.07 \mathrm{E}-02$ & $1.01 \mathrm{E}-02$ & $1.61 \mathrm{E}-02$ & $\mathrm{~kg}$ \\
\hline Poultry manure & $4.50 \mathrm{E}-01$ & $1.03 \mathrm{E}-02$ & $3.76 \mathrm{E}-03$ & $\mathrm{~kg}$ \\
\hline Pesticides & $7.96 \mathrm{E}-04$ & $1.10 \mathrm{E}-04$ & 5.54E-04 & $\mathrm{Kg}$ \\
\hline Weedicide & $8.06 \mathrm{E}-04$ & $6.11 \mathrm{E}-04$ & $1.58 \mathrm{E}-03$ & $\mathrm{~kg}$ \\
\hline Land use & $1.31 \mathrm{E}-04$ & $1.58 \mathrm{E}-06$ & $1.03 \mathrm{E}-05$ & ha \\
\hline Dried wood (2-3\% moisture content) & 7.81E-02 & $7.28 \mathrm{E}-02$ & 7.35E-02 & $\mathrm{kg}$ \\
\hline \multicolumn{5}{|l|}{ Product } \\
\hline Charcoal & $3.68 \mathrm{E}-02$ & $3.42 \mathrm{E}-02$ & $3.46 \mathrm{E}-02$ & $\mathrm{~kg}$ \\
\hline \multicolumn{5}{|l|}{ Air emissions } \\
\hline Dust (particles to air) & $6.96 \mathrm{E}-08$ & $6.99 \mathrm{E}-07$ & 8.82E-07 & $\mathrm{kg}$ \\
\hline Sulphur dioxide (inorganic emission to air) & $3.56 \mathrm{E}-08$ & 3.38E-07 & $3.02 \mathrm{E}-07$ & $\mathrm{~kg}$ \\
\hline Heavy metals to air & $1.73 \mathrm{E}-12$ & $3.06 \mathrm{E}-12$ & $2.97 \mathrm{E}-11$ & $\mathrm{~kg}$ \\
\hline Carbon dioxide (inorganic emission to air) & $1.38 \mathrm{E}-07$ & $5.16 \mathrm{E}-06$ & $5.10 \mathrm{E}-07$ & $\mathrm{~kg}$ \\
\hline Carbon monoxide (inorganic emission to air) & 8.24E-09 & $1.13 \mathrm{E}-08$ & $1.18 \mathrm{E}-08$ & $\mathrm{~kg}$ \\
\hline Pesticides to air & $1.98 \mathrm{E}-08$ & $5.78 \mathrm{E}-08$ & 4.07E-08 & $\mathrm{kg}$ \\
\hline \multicolumn{5}{|l|}{ Water emissions } \\
\hline Biological oxygen demand & $1.41 \mathrm{E}-16$ & $1.41 \mathrm{E}-16$ & $1.78 \mathrm{E}-17$ & $\mathrm{~kg}$ \\
\hline Nitrates & 4.42E-17 & $4.12 \mathrm{E}-16$ & $4.14 \mathrm{E}-16$ & $\mathrm{~kg}$ \\
\hline Oil and grease & 8.94E-21 & $8.41 \mathrm{E}-21$ & $4.62 \mathrm{E}-22$ & $\mathrm{~kg}$ \\
\hline Phosphates & $2.43 \mathrm{E}-20$ & $9.13 \mathrm{E}-20$ & $9.03 \mathrm{E}-20$ & $\mathrm{~kg}$ \\
\hline Total dissolved solids & 7.29E-18 & $6.85 \mathrm{E}-18$ & $6.77 \mathrm{E}-18$ & $\mathrm{~kg}$ \\
\hline Total suspended solids & $3.11 \mathrm{E}-16$ & $1.47 \mathrm{E}-16$ & $2.06 \mathrm{E}-16$ & $\mathrm{~kg}$ \\
\hline Heavy metals to freshwater & $2.08 \mathrm{E}-08$ & $1.96 \mathrm{E}-08$ & $2.07 \mathrm{E}-08$ & $\mathrm{~kg}$ \\
\hline Pesticides to freshwater & $1.66 \mathrm{E}-08$ & $1.54 \mathrm{E}-07$ & $1.53 \mathrm{E}-07$ & $\mathrm{Kg}$ \\
\hline \multicolumn{5}{|l|}{ Soil emissions } \\
\hline Pesticides to soil & $3.58 \mathrm{E}-09$ & $2.47 \mathrm{E}-08$ & 2.61E-08 & $\mathrm{kg}$ \\
\hline Heavy metals to soil & $1.90 \mathrm{E}-09$ & $1.75 \mathrm{E}-09$ & $1.75 \mathrm{E}-10$ & $\mathrm{~kg}$ \\
\hline
\end{tabular}


Table 3 Set of multipliers for the emissions of toxic substances used in the eco-costs 2012 system

\begin{tabular}{ll}
\hline Category & Multipier (marginal prevention costs \\
\hline Eco-costs of acidification & $8.25 € / \mathrm{kg} \mathrm{SOx}$ equivalent \\
Eco-costs of eutrophication & $3.90 € / \mathrm{kg}$ phosphate equivalent \\
Eco-costs of ecotoxicity & $55.0 € / \mathrm{kg} \mathrm{Zn} \mathrm{equivalent}$ \\
Eco-costs of human toxicity & $36.0 € / \mathrm{kg} \mathrm{Benzo(a)pyrene} \mathrm{equivalent}$ \\
Eco-costs of summer smog (respiratory diseases) & $9.70 € / \mathrm{kg} \mathrm{C}_{2} \mathrm{H}_{4}$ equivalent \\
Eco-costs of fine dust & $34.0 € / \mathrm{kg}$ fine dust PM2.5 \\
Eco-costs of global warming & $0.135 € / \mathrm{kg} \mathrm{CO}_{2}$ equivalent (GWP 100)
\end{tabular}

Source: Ecocostvalue website (http://www.ecocostsvalue.com/EVR/model/theory/subject/2-eco-costs.html). These multipliers were used in calculating the total eco-cost, comprising the sum of four endpoint impact categories (eco-costs of human health, eco-costs of ecosystems, eco-costs of resource depletion and eco-costs of global warming) was used as the indicator for assessing environmental impacts. The four endpoint impact categories were calculated as follows: eco-costs of human health $=$ the sum of carcinogens, fine dust; eco-costs of ecosystems $=$ the sum of acidification, eutrophication, ecotoxicity; eco-costs of resource depletion $=$ the sum of abiotic depletion, land-use, water, and land-fill; eco-costs of global warming = the sum of $\mathrm{CO}_{2}$ and other greenhouse gases 
Table 4 Total eco-cost associated with the flow processes for $1 \mathrm{MJ}$ energy content of charcoal produced from T. grandis, A. auriculiformis and B. balcooa plantations in Ghana

\begin{tabular}{|c|c|c|c|c|c|c|c|}
\hline Species & Process & $\begin{array}{l}\text { Eco-costs of } \\
\text { human health } \\
(€ / F U)\end{array}$ & $\begin{array}{l}\text { Eco-cost of } \\
\text { ecosystems } \\
(€ / F U)\end{array}$ & $\begin{array}{l}\text { Eco-cost of } \\
\text { global } \\
\text { warming } \\
(€ / F U)\end{array}$ & $\begin{array}{l}\text { Eco-cost of } \\
\text { resource } \\
\text { depletion } \\
(€ / F U)\end{array}$ & $\begin{array}{l}\text { Total eco- } \\
\text { costs } \\
(€ / F U)\end{array}$ & $\%$ \\
\hline \multirow[t]{4}{*}{ T. grandis } & Nursery & $4.77 \mathrm{E}-08$ & $8.70 \mathrm{E}-07$ & $1.56 \mathrm{E}-06$ & $1.86 \mathrm{E}-07$ & $2.66 \mathrm{E}-06$ & 60 \\
\hline & Field plantation & $1.90 \mathrm{E}-08$ & 4.68E-08 & $2.36 \mathrm{E}-07$ & $7.44 \mathrm{E}-07$ & $1.05 \mathrm{E}-06$ & 23 \\
\hline & Harvesting & $9.77 \mathrm{E}-08$ & $2.03 \mathrm{E}-08$ & 2.61E-09 & $1.99 \mathrm{E}-08$ & $1.41 \mathrm{E}-07$ & 3 \\
\hline & Total ecocost $(€) / \mathrm{FU}$ & 4.92E-07 & $9.46 \mathrm{E}-07$ & $1.99 \mathrm{E}-06$ & $1.03 \mathrm{E}-06$ & $4.46 \mathrm{E}-06$ & 100 \\
\hline \multirow[t]{3}{*}{ B. balcooa } & Nursery & $6.89 \mathrm{E}-09$ & $1.25 \mathrm{E}-08$ & $1.15 \mathrm{E}-07$ & 2.69E-09 & $1.37 \mathrm{E}-07$ & 4 \\
\hline & Field plantation & 3.19E-08 & $8.00 \mathrm{E}-09$ & $1.37 \mathrm{E}-06$ & $1.26 \mathrm{E}-06$ & $2.67 \mathrm{E}-06$ & 84 \\
\hline & Harvesting & $9.43 \mathrm{E}-09$ & $1.95 \mathrm{E}-09$ & 2.71E-08 & 1.92E-09 & 4.04E-08 & 1 \\
\hline \multirow[t]{6}{*}{ A. auriculiformis } & Nursery & 2.73E-08 & $5.02 \mathrm{E}-07$ & $6.97 \mathrm{E}-07$ & $1.07 \mathrm{E}-07$ & $1.33 \mathrm{E}-06$ & 37 \\
\hline & Field plantation & $1.47 \mathrm{E}-08$ & $3.74 \mathrm{E}-08$ & $1.11 \mathrm{E}-06$ & $5.90 \mathrm{E}-07$ & $1.76 \mathrm{E}-06$ & 49 \\
\hline & Harvesting & 8.08E-08 & $1.67 \mathrm{E}-08$ & 2.23E-08 & 1.65E-08 & $1.36 \mathrm{E}-07$ & 4 \\
\hline & Pyrolysis/carbonization & $8.68 \mathrm{E}-09$ & $1.13 \mathrm{E}-09$ & $1.44 \mathrm{E}-08$ & $1.06 \mathrm{E}-08$ & $3.48 \mathrm{E}-08$ & 1 \\
\hline & Transportation & $2.66 \mathrm{E}-07$ & $2.85 \mathrm{E}-09$ & $3.55 \mathrm{E}-08$ & $2.58 \mathrm{E}-08$ & $3.31 \mathrm{E}-07$ & 9 \\
\hline & Total ecocost $(€ / F U)$ & $3.98 \mathrm{E}-07$ & $5.60 \mathrm{E}-07$ & $1.88 \mathrm{E}-06$ & $7.50 \mathrm{E}-07$ & $3.59 \mathrm{E}-06$ & 100 \\
\hline
\end{tabular}

$\mathrm{FU}=$ functional unit 